Emir. J. Food Agric. 2008. 20 (2): 10-17

http://www.cfa.uaeu.ac.ae/research/ejfa.htm

\title{
Effect of aqueous extract of the invasive species Tobacco (Nicotiana glauca L.) on seedlings growth of Juniper (Juniperus procera L.)
}

\author{
Thobayet S. Alshahrani \\ Plant Production Dept, College of Food and Agriculture Sciences, King Saud \\ University, Riyadh, P.O. Box 2460, Riyadh 11451, Saudia Arabia
}

\begin{abstract}
This study was conducted to evaluate the allelopathic effects of aqueous extracts from different vegetative parts (root, stem, and leaf) of the invasive exotic species Nicotiana glauca on seedling growth of a native species Juniperus procera. Two concentrations of $5 \mathrm{~g} / \mathrm{l}$ and $20 \mathrm{~g} / \mathrm{l}$ were employed in the treatment. Stem extracts of both concentrations increased the seedlings' mortality over $88 \%$. Extracts had a negative effect on root dry weight $(\mathrm{P}=0.015)$ and root to shoot ratio $(\mathrm{P}=0.004)$. Root and leaf extracts showed different effects on seedling growth parameters such as total root length, root surface area, root volume, number of root tips, root dry weight, shoot dry weight, and root to shoot ratio . Leaf extract promoted growth with increasing concentration, while root extract deterred growth parameters.
\end{abstract}

Keywords: Allelopathy, invasive species, Juniperus procera, Nicotiana glauca.
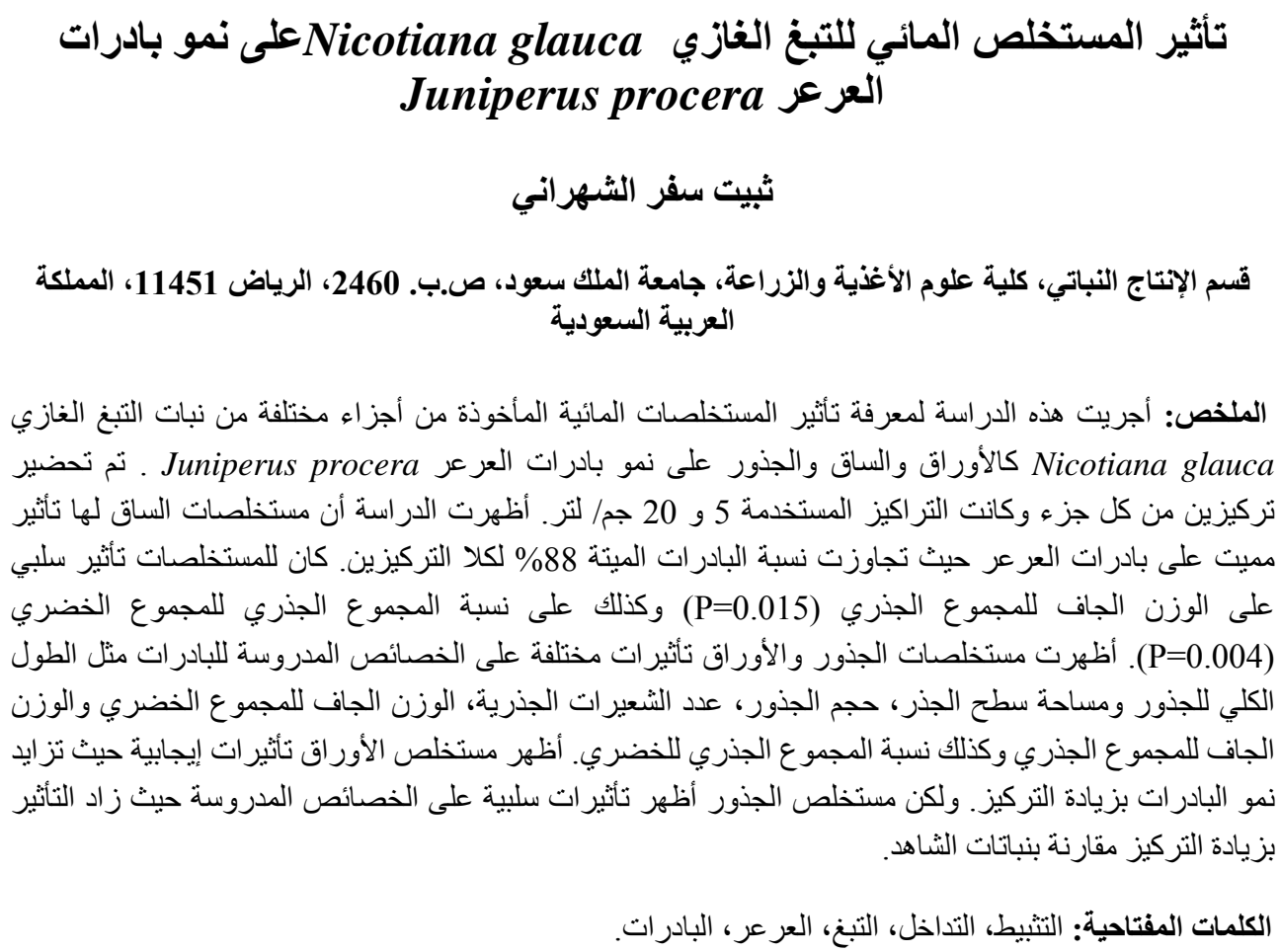

\section{Introduction}

Nicotiana glauca is an exotic species that may soon become an obnoxious weed in the Southwestern part of Saudi Arabia. The extensive amount of rainfall and moderate temperature may help the species invade new areas and expand its range. Rapid germination, with no specific requirements enhances its ability to invade new sites and deplete resources before the native species. N. glauca is a toxic plant (Plumlee et al., 1993) and 
the aqueous leachate of its parts exhibit allelopathic effects (Florentine and Westbrooke, 2005). Heisey and Delwiche (1983) found that extracts of $N$. glauca had strong inhibitory effects in a comparative study with 55 allelopathic plants in northern California. For invasive species, changing the physical and chemical environment is used as a mechanism to prevent seed germination and seedlings growth of native species. The lack of co-evolved tolerance of resident species to new chemicals produced by the invader allows the invading species to dominate plant communities quickly (Hierro and Callaway, 2003). Juniperus procera (Hochst. ex Endl.) is one of the most important native plants in the southwestern part of Saudi Arabia and interaction with $N$. glauca may affect one or more of its stages, like seed germination and seedling growth. In other Juniper species like Juniperus occidentalis ssp. Occidentalis, growth rates under favorable conditions were 1.4 to $3.4 \mathrm{~cm} / \mathrm{yr}$ (Miller and Rose, 1995; Burkhardt and Tisdale, 1976; Kramer, 1990). Slow growth in $J$. procera seedlings which is an inherent feature may reduce its ability to survive. The aim of this study was to evaluate the allelopathic impact of the invasive species $N$. glauca on seedlings growth of the native $J$. procera as no other study was undertaken previously on this aspect.

\section{Materials and Methods}

N. glauca was grown to maturity in greenhouse conditions. Leaves, stems and roots were collected from fully mature plants and oven dried at $65^{\circ} \mathrm{C}$ for 48 hours. To prepare the extract, the parts were soaked separately in distilled water for $24 \mathrm{hr}$ at $27^{\circ} \mathrm{C}$ at the rate of 5 , $20 \mathrm{gl}^{-1}$ (W: V). The extracts were filtered through Whatman filter paper using vacuum and stored in plastic containers in a refrigerator at $5^{\circ} \mathrm{C}$ until further use. More extracts were prepared as needed.

The greenhouse experiment was conducted to determine the allelopathic effect of $N$. glauca on $J$. procera seedlings. In order to establish the plants, seeds of J. procera were sown in Petri dishes and after germination two seedlings were transplanted into a plastic tube $60 \mathrm{~cm}$ height and $5 \mathrm{~cm}$ in diameter filled with sand as recommended by Alsaadawi et al., (1986). The experiment was set in a completely randomized design. Seedlings were grown in a growth chamber at $30^{\circ} \mathrm{C}, 25^{\circ} \mathrm{C}(\mathrm{D} / \mathrm{N})$ and $12 / 12 \mathrm{hr}$ (L/D) photoperiod. Four tubes (replicates) represented each concentration (treatment) with 2 plants per tube. After leaf emergence (8 weeks), the seedlings were irrigated weekly with $50 \mathrm{ml}$ of leaf, stem and root extracts. Untreated plants (control) received the same amount of distilled water $\left(0 \mathrm{gl}^{-1}\right)$. Also, $40 \mathrm{~mL}$ of Hogland's solution (Hogland and Arnon, 1950) was used to fertilize seedlings once a week throughout the experiment.

After 8 months, the plants were harvested and the shoots were separated from the roots. Prior to root measurement, sand was removed by washing with water gently to reduce root loss. Roots of the pair of plants in each container were separated and transferred to moist plastic bags for individual measurements. Fresh weight measurements were not taken to avoid root destruction. Roots for each seedling were scanned at 600 dpi and analyzed with WinRhizo basic software (Regent Instruments Inc., Quebec, Canada). With WinRhizo, variables like total root length $(\mathrm{cm})$, root volume $\left(\mathrm{cm}^{3}\right)$, root surface area $\left(\mathrm{cm}^{2}\right)$, and number of root tips were measured. After scanning, roots were dried at $75^{\circ} \mathrm{C}$ for $48 \mathrm{hr}$ to obtain dry weights. Later, data was analyzed with SAS (SAS, 
2005) and an L.S.D test was used to compare means.

\section{Results and Discussion}

Allelopathy has been suggested as the key strategy for the impressive success of many invasive plants that have become dominant in their invaded plant communities (Ridenour and Callaway, 2001). Plant tissues vary in their allelopathic potential on the target plant, where some allelochemical substances have a stimulating effect on the growth of the recipient plant at low concentrations (Buta and Spaulding, 1989). Many plants produce allelochemical compounds, but some have no negative effect because either biotic or abiotic triggering factors are lacking in soil (An et al., 2001).
Allelochemical compounds may be selective in their action, or plants may be selective in their response (Zeng et al., 2001). J. procera showed different patterns of sensitivity depending on the source of extracts from $N$. glauca where stem extract, in both concentrations, induced mortality up to $88 \%$ in $J$. procera seedlings within one week of treatment. Competitive strategies for resources and neighbor suppression allow invasive species' populations to aggressively take over a site or community by increasing the mortality of native species (Fischer et al., 1994; Tilman, 1988). Nicotiana glauca extracts had no significant effect on the seedling shoot dry weight $(\mathrm{P}=0.6488)$. However, shoot dry weight decreased with increasing extract concentrations for both leaf and root (Fig. 1).

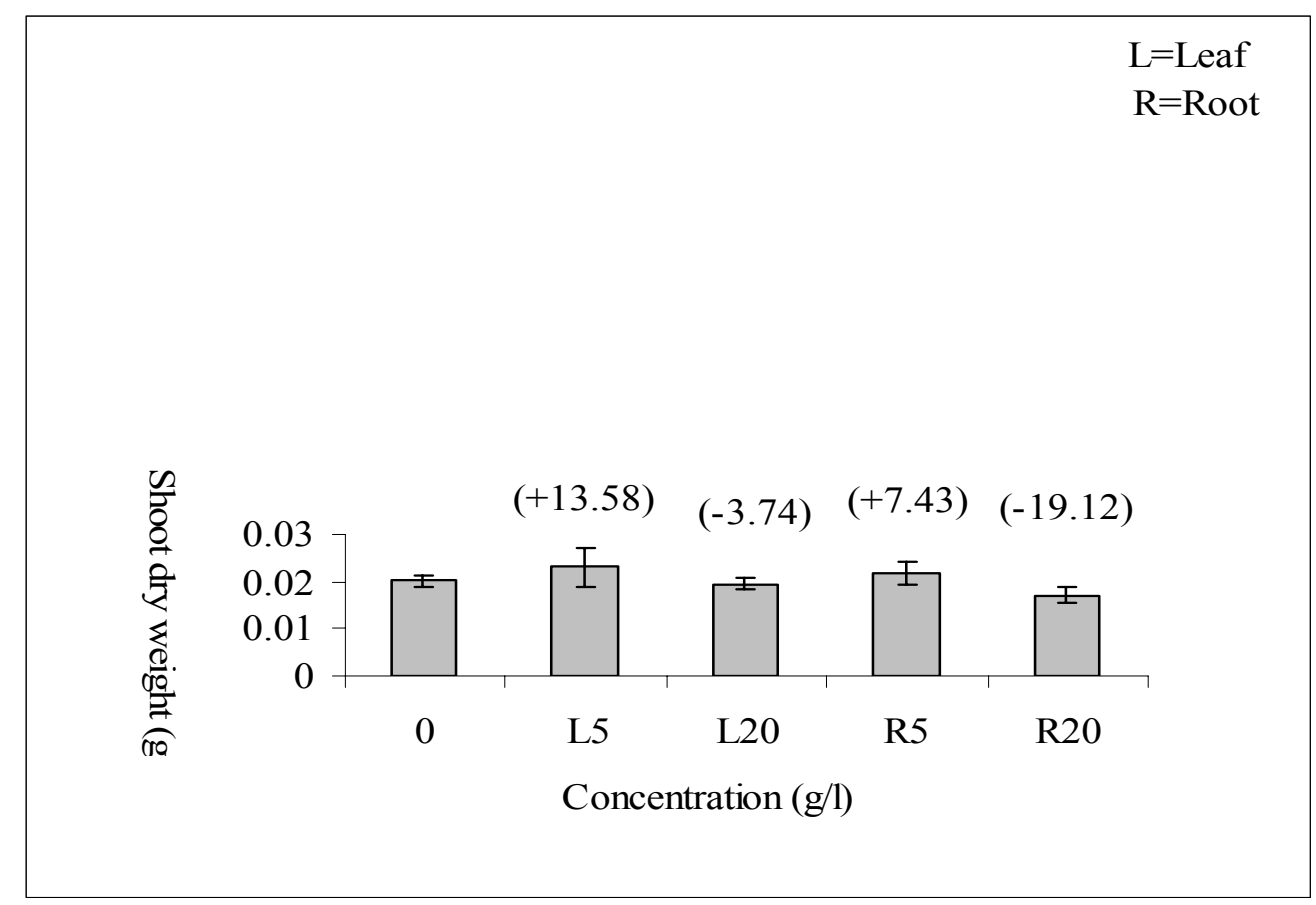

Figure 1. Impact of $N$. glauca part extracts on shoot dry weight of

Juniperus procera. Values in parentheses are \%increase $(+)$ or decrease (-) with references to control $\left(0 \mathrm{~g} \mathrm{l}^{-1}\right)$.

Analysis of variance showed that $N$. glauca extracts had significant effects on $J$. procera root dry weight (0.0159). Response from $J$. procera varied with the source of extract. Increasing concentrations of leaf extract promoted root dry weight, but it (the root dry weight) decreased with increasing root extract concentrations (Fig. 2). The low relative allocation of biomass to root 
with increasing root extract concentration may reflect a condition of stress. Root architecture under natural conditions could have a large bearing on such processes. In this study, the seedlings' root system in J. procera was shallow which in turn maximized inhibitory effects of $N$. glauca due to increased presence of allelopathic substances. However, the efficacy of allelopathic compounds can also vary depending on the donor part of the source plant. For instance, in $P$. juliflora, fruit extracts were inhibited to shoot growth of different cultivated plants when compared to extracts of root, stem, leaf and flower. Interestingly, the root extracts of $P$. juliflora significantly promoted seedling growth of Triticum aestivum and Zea mays (Noor et al., 1995). Root extracts of $N$. glauca affected $J$. procera root growth parameters negatively. Tefera (2002) found that extracts from flower, root and stem of Parthenium hysterophorus stimulated shoot length of Eragrostis tef at all concentration levels, but aqueous extracts from leaf and flower inhibited root length.

Analysis of variance indicated that $N$. glauca had a significant effect on root to shoot ratio of $J$. procera $(\mathrm{P}=0.004)$. However, the effect depends on plant parts first, the, on the concentration of the extract. By increasing the concentration of leaf extract, root to shoot ratio increased but the opposite was observed with the root extracts (Fig. 3). It is obvious that leaf extracts in some cases may provide inorganic nutrients that enhance root growth (Butcko and Jensen, 2002; Heisey, 1990).

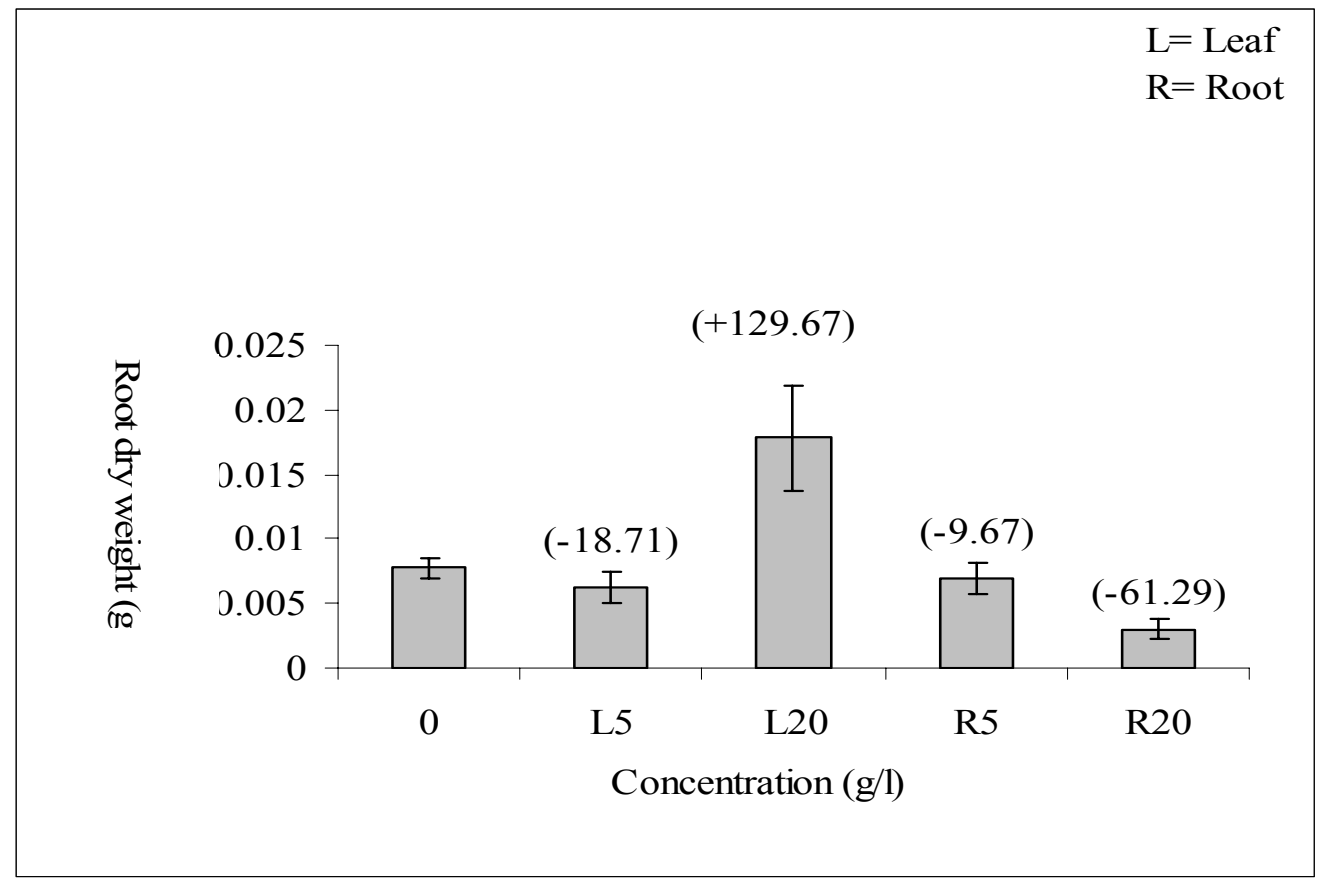

Figure 2. Impact of $N$. glauca part extracts on root dry weight of Juniperus procera. Values in parentheses are $\%$ increase $(+)$ or decrease $(-)$ with references to control $\left(0 \mathrm{~g} \mathrm{I}^{-1}\right)$. 
Emir. J. Food Agric. 2008. 20 (2): 10-17

http://www.cfa.uaeu.ac.ae/research/ejfa.htm

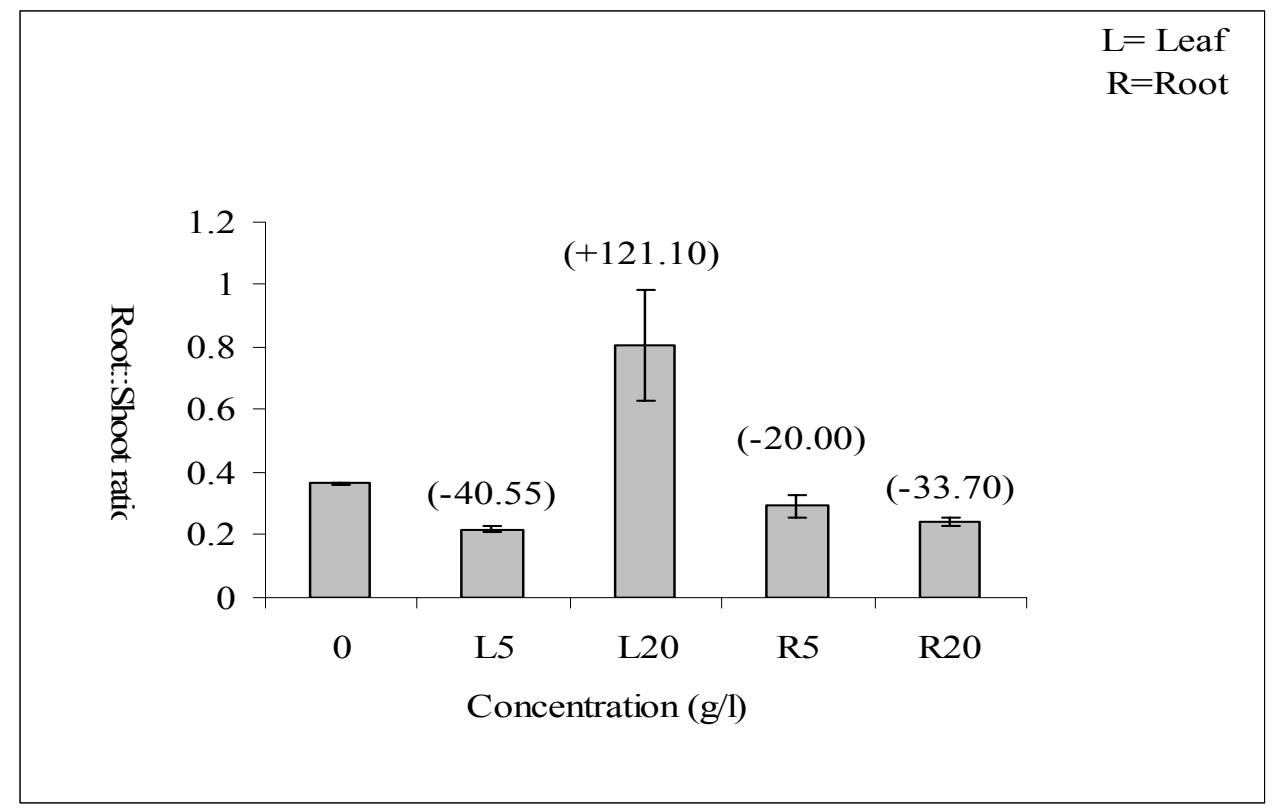

Figure 3. Impact of $N$. glauca part extracts on root to shoot ratio of Juniperus procera. Values in parentheses are \% increase $(+)$ or decrease (-) with references to control $\left(0 \mathrm{~g} \mathrm{l}^{-1}\right)$.

Nicotiana glauca extracts had no significant effect on total root length $(\mathrm{P}=0.0880)$. However, root length increased with increasing leaf extract concentration, but total root length reduced with increasing root extract concentrations (Table 1). It seemed that the $J$. procera seedlings were stimulated by leaf extracts, but inhibited by root extracts. The reduction in the growth of $J$. procera may be due to allelopathy that induced inhibition of nutrient uptake (Ismail and Chong, 2002). Nutrient uptake correlates with root characteristics such as its length. Increasing root extract concentration of $N$. glauca induced a reduction in total root length. There was a strong correlation between total root length and root volume ( $r=0.78$, Table 2$)$, and root volume and number of tips $(r=0.85$, Table 2).

Extracts of $N$. glauca had no significant effect on the number of root tips $(\mathrm{P}=0.3202)$. In general, the amount of root tips increased slightly with increasing leaf extract concentration and reduced with increasing root extract (Table 1). Also, extracts of $N$. glauca had no significant effect on root volume of the $J$. procera seedlings $(\mathrm{P}=0.1695)$, but root volume decreased with increasing root extract concentration. Therefore the reduction in root volume indicated a negative effect of $N$. glauca (Table 1). In general, reduction in root volume limits nutrient and water supply to shoots, consequently decreasing shoot growth. Allelopathic compounds can change the morphology of the receptor plant. Kim et al. (1995) found a change in the structure of root tips of the species Raphanus sativus var. hortensis after treatment with various concentrations of the leaf extract of Pinus rigida. N. glauca extracts, however, had no significant effect on root surface area $(\mathrm{P}=0.1966)$. It was clear that root surface area increased with increasing concentrations of leaf extract, but the reverse was observed with root extracts (Table 1). Differences might be related to allelopathic compounds being produced in larger 
quantities in certain tissues, imposing a higher level of inhibition, compared to others (Chon and Kim, 2002). Chou and Leu (1992) found that aqueous extract of leaves, flowers, and twigs of Delonix regia showed different patterns of toxicity, and found that the highest inhibition was observed with floral extracts. The degree of inhibition increased with an increase in concentrations of the extracts.

The relevance of this study to field conditions, and more specifically the invasive behavior of $N$. glauca when growing in association with $J$. procera is unclear. However, under field conditions in dry climates, such as in Saudi Arabia, litter may accumulate and increase the concentrations of allelochemicals when rains occur
(Alshahrani et al., 2009). These periodic flushes of allelochemicals may be sufficient to impact other plants. Such a scenario could enable an invasive exotic species such as $N$. glauca to gain competitive advantages over native species' seedlings like $J$. procera. Expansion of invasive species depends on the ecology of the invaded communities and in many cases, the density. For example, Phalaris arundinacea invades disturbed or lowdensity plant communities (Morrison and Molofsky, 1998). However, plant communities with high biomass production tend to be less conducive to invasion because litter accumulation inhibits seedling establishment of the invasive species (Burke and Grime, 1996).

Table 1. Means and standard error of the effects of $N$. glauca aqueous extracts of leaf and root on root parameters of Juniperus procera.

\begin{tabular}{|c|c|c|c|c|c|c|}
\hline $\begin{array}{l}\text { Extract } \\
\text { sources }\end{array}$ & $\begin{array}{c}\text { Concentration } \\
(\mathrm{g} / \mathrm{l})\end{array}$ & $\begin{array}{l}\text { Total root } \\
\text { length }(\mathrm{cm})\end{array}$ & $\begin{array}{c}\text { Root } \\
\text { surface } \\
\text { area }\left(\mathrm{cm}^{2}\right)\end{array}$ & $\begin{array}{c}\text { Root } \\
\text { volume } \\
\left(\mathrm{cm}^{3}\right)\end{array}$ & $\begin{array}{c}\text { Number } \\
\text { of root } \\
\text { tips }\end{array}$ & $\begin{array}{c}\text { Root } \\
\text { average } \\
\text { diameter } \\
(\mathbf{m m}) \\
\end{array}$ \\
\hline & 0 & $\begin{array}{l}19.38^{\mathrm{b}} \\
\pm 0.34\end{array}$ & $\begin{array}{l}2.68^{\mathrm{ab}} \\
\pm 0.13\end{array}$ & $\begin{array}{c}0.03^{\mathrm{ab}} \\
\pm 0.003\end{array}$ & $\begin{array}{c}15^{\mathrm{a}} \\
\pm 0.97\end{array}$ & $\begin{array}{l}0.43^{\mathrm{a}} \\
\pm 0.01\end{array}$ \\
\hline \multirow[b]{2}{*}{ Leaf } & 5 & $\begin{array}{c}19.46^{\mathrm{b}} \\
\pm 1.51 \\
(+0.41)^{*}\end{array}$ & $\begin{array}{l}2.61^{\mathrm{ab}} \\
\pm 0.32 \\
(-2.6)^{*}\end{array}$ & $\begin{array}{c}0.023^{\mathrm{ab}} \\
\pm 0.004 \\
(-23.3)^{*}\end{array}$ & $\begin{array}{c}13^{\mathrm{a}} \\
\pm 0.88 \\
(-13.3)^{*}\end{array}$ & $\begin{array}{c}0.41^{\mathrm{ab}} \\
\pm 0.02 \\
(-4.65)^{*}\end{array}$ \\
\hline & 20 & $\begin{array}{c}25.28^{\mathrm{a}} \\
\pm 0.94 \\
(+30.44)^{*}\end{array}$ & $\begin{array}{c}3.27^{\mathrm{a}} \\
\pm 0.06 \\
(+22)^{*}\end{array}$ & $\begin{array}{c}0.03^{\mathrm{ab}} \\
\pm 0.0004 \\
(0.00)^{*}\end{array}$ & $\begin{array}{c}14^{\mathrm{a}} \\
\pm 1.12 \\
(-6.7)^{*}\end{array}$ & $\begin{array}{c}0.41^{\mathrm{ab}} \\
\pm 0.008 \\
(-4.65)^{*}\end{array}$ \\
\hline \multirow[t]{2}{*}{ Root } & 5 & $\begin{array}{c}22.67^{\mathrm{ab}} \\
\pm 2.72 \\
(+17)^{*}\end{array}$ & $\begin{array}{c}3.09^{\mathrm{ab}} \\
\pm 0.48 \\
(+15.3)^{*}\end{array}$ & $\begin{array}{c}0.038^{\mathrm{a}} \\
\pm 0.008 \\
(+26.7)^{*}\end{array}$ & $\begin{array}{c}19^{\mathrm{a}} \\
\pm 3.60 \\
(+26.7)^{*}\end{array}$ & $\begin{array}{c}0.42^{\mathrm{ab}} \\
\pm 0.01 \\
(-2.32)^{*}\end{array}$ \\
\hline & 20 & $\begin{array}{c}18.1^{\mathrm{b}} \\
\pm 0.88 \\
(-6.6)^{*}\end{array}$ & $\begin{array}{c}2.13^{\mathrm{b}} \\
\pm 0.13 \\
(-20.5)^{*}\end{array}$ & $\begin{array}{c}0.02^{b} \\
\pm 0.0004 \\
(-33.3)^{*}\end{array}$ & $\begin{array}{c}13^{\mathrm{a}} \\
\pm 1.22 \\
(-13.3)^{*}\end{array}$ & $\begin{array}{c}0.37^{\mathrm{b}} \\
\pm 0.004 \\
(-13.95)^{*}\end{array}$ \\
\hline
\end{tabular}

*Values in italic between parentheses are \% increase $(+)$ or decrease $(-)$ with references to control $\left(0\right.$ g. $\left.1^{-1}\right)$. 
Emir. J. Food Agric. 2008. 20 (2): 10-17

http://www.cfa.uaeu.ac.ae/research/ejfa.htm

Table 2. Correlation between root parameters.

\begin{tabular}{|c|c|c|c|c|}
\hline & $\mathbf{L}$ & SA & $\mathbf{V}$ & ${ }^{\mathrm{e}} \mathbf{R D W}$ \\
\hline \multicolumn{5}{|l|}{${ }^{a} \mathrm{~L}$} \\
\hline \multirow[t]{2}{*}{${ }^{\mathrm{b}} \mathrm{SA}$} & 0.9566 & & & \\
\hline & 0.0001 & & & \\
\hline \multirow[t]{2}{*}{${ }^{c} \mathrm{~V}$} & 0.7832 & 0.8953 & & \\
\hline & 0.0001 & 0.0001 & & \\
\hline \multirow[t]{2}{*}{ TIPS } & 0.7682 & 0.8166 & 0.8562 & \\
\hline & 0.0001 & 0.0001 & 0.0001 & \\
\hline \multirow[t]{2}{*}{${ }^{d} \mathrm{RSR}$} & NS & NS & NS & 0.9319 \\
\hline & & & & 0.0001 \\
\hline
\end{tabular}

\section{Conclusion}

This study provides evidence on the allelopathic potential of $N$. glauca. In order to fully investigate the allelopathic impacts of invasive species on native plants, studies under field conditions need to be conducted. But in slow-growing species such as $J$. procera impacts can only be determined through long-term studies.

\section{References}

Alsaadawi, I., S. Al-hadithy and M. Arif. 1986. Effects of three phenolic acids on chlorophyll content and ion uptake in cowpea seedlings. J. Chem. Ecol. $12: 221-227$.

Alshahrani, T. S., R. R. Hicks, S. Verlinden and G. E. Siedel. 2009. Effects of leaf extracts of Zizyphus spina-christi and prosopis juliflora on each others seedlings roots. Allelopathy Journal 23(1):111-119.

An, M., J. E. Pratley and T. Haig. 2001. Phtotoxicity of vulpia residues: IV. Dynamics of allelochemicals during decomposition of vulpia residues and their corresponding phytotoxicity. J. Chem. Ecol. 27:395-409.

Burke, M. J. and J. P. Grime. 1996. An experimental study of plant community invisibility. Ecology 77:776-790.

Burkhardt, J. W. and E. W. Tisdale. 1976. Causes of Juniper invasion in Southwestern Idaho. Ecology 57:472484.

Buta, J. G. and D. W. Spaulding. 1989. Allelochemical in tall fescuse abscisic and phenolic acids. J. Chem. Eco. 15:1629-1636.

Butcko, V. M. and R. Jensen. 2002. Evidence of tissue specific allelopathic activity in Euthamia graminifolia and Solidago canadensis (Asteraceae). The Amer. Mid. Nat. 148:253-262.

Chon, S. U. and J. D. Kim. 2002. Biological activity and quantification of suspected allelochemicals from alfalfa plant parts. J. Agr. Crop Sci. 188:281-285.

Chou, C. H. and L. L. Leu. 1992. Allelopathic substances and interactions of Delonix regia. J. Chem. Ecol. 18:2285-2303.

Fischer, N. H., G. B. Williamson, J. D. Weidenhamer and D. R. Richardson. 1994. In search of allelopathy in the Florida scrub. The role of terpenoids. J. Chem. Ecol. 20:1355-1380. 
Florentine, S. K. and M. E Westbrooke. 2005. Invasion of the noxious weed Nicotiana glauca R. Graham after an episodic flooding event in the arid zone of Australia. J. Arid Environ. 4:531-545.

Heisey, R. M. and C. C. Delwiche. 1983. A survey of California plants for water-extractable and volatile inhibitors. Bot. Gaz. 144:382-390.

Heisey, R. M. 1990. Evidence for allelopathy by tree of heaven (Ailanthus altissima). J. Chem. Ecol. 16:2039-2055.

Hierro, J. L. and R. M. Callaway. 2003. Allelopathy and exotic plant invasion. Plant Soil 256:29-39.

Hoagland, D. R. and D. I. Arnon. 1950. The water-culture method for growing plants without soil. Cal. Agri. Expt. Sta. Circ. 347:1-32.

Ismail, B. S. and T. V. Chong. 2002. Effect of aqueous extracts and decomposition of Mikania micrantha H.B.K. debris on selected agronomic crops. Weed Biol. Manag. 2:31-38.

Kim, Y. O., H. J. Lee, E. S. Kim and Y. D. Cho. 1995. Effect of leaf extract from Pinus rigida on morphological changes of root tips. J. Plant Biol. 38:73-78.

Kramer, S., 1990. Development and morphology of juvenile western juniper (Juniperus occidentalis Hook.). M.S. Thesis, Oregon State University, Corvallis, OR. (Abstract)

McKinley, D. and O. W Van-Auken. 2004. Growth and survival of Juniperus ashei (Cupressacae) seedlings in the presence of Juniperus ashei litter. Tex. J. Sci. 56:3-14.
Miller, R. F. and J. A. Rose. 1995. Historic expansion of western juniper (Juniperus occidentalis) in southeastern Oregon. Great Basin Nat. $55: 37-45$.

Morrison, S. and J. Molofsky. 1998. Effects of genotypes, soil moisture, and competition on the growth of an invasive grass, Phalaris arundinacea (reed canary grass). Can. J. Botany. 76:1939-1946.

Noor, M., U. Salam and A. Khan. 1995. Allelopathic effects of Prosopis juliflora Swartz. J. Arid Environ. 31:83-90.

Plumlee, K H., D. M. Holstege, P. C Blanchard, K. M. Fiser and F. D. Galey. 1993. Nicotiana glauca toxicosis of cattle. J. Vet. Diagn. Invest. 5:498-499

Ridenour, W. M. and R. M. Callaway. 2001. The relative importance of allelopathy in interference: the effects of an invasive weed on a native bunchgrass. Oecologia. 126:444-450.

SAS. 2005. User 's Guide Statistical Analysis System, Edition 9.1.3.

Tefera, T. 2002. Allelopathic effects of Parthenium hysterophorus extracts on seed germination and seedling growth of Eragrostis tef. J. Agron.Crop Sci. 188:306-310.

Tilman, D. 1988. Plant strategies and the dynamics and structure of plant communities. Princeton University Press, New Jersey.

Zeng, R. S., S. M. Luo, Y. H. Shi, M. B. Shi and C. Y. Tu. 2001. Physiological and biochemical mechanism of allelopathy of Secalonic Acid F on higher plants. Agron. J. 93:72-79. 
Emir. J. Food Agric. 2008. 20 (2): 10-17

http://www.cfa.uaeu.ac.ae/research/ejfa.htm 